Journal of

Dentistry and Oral Health

\title{
Oral Hygiene Practice and Its Relation with Stress among the Adult Patient Visiting the National Guard Hospital and Military Hospital in Madinah
}

\author{
Omar Ghulam ${ }^{1, *}$, Ahmed W.Tola ${ }^{2}$, Mohanad A.Al-Saedi ${ }^{3}$ \\ ${ }^{1}$ Prince Mohammed Bin Abdulaziz Hospital, National Guard Health Affairs, Madinah, Saudi Arabia \\ ${ }^{2}$ General Dentist, Prince Sultan Military Hospital, Defense Ministry, Madinah, Saudi Arabia \\ ${ }^{3}$ Intern, Prince Sultan Military Hospital, Defense Ministry, Madinah, Saudi Arabia
}

*Corresponding author: Omar Ghulam , prince mohammed bin abdulaziz hospital -national guard health affaire and prince sultan hospital -ministry of defence Maddinah-Saudi Arabia; E-mail: omarghlam@gmail.com

Received Date: December 07, 2017; Accepted Date: February 05, 2018; Published Date: February 08, 2018

Citation: Omar Ghulam (2018) Oral Hygiene Practice and Its Relation with Stress among the Adult Patient Visiting the National Guard Hospital and Military Hospital in Madinah. J Dent Oral Health 5: 1-7.

\begin{abstract}
Background: Stress is increasing day by day in everyone's life and it is likely to contribute to the progressive long term development of oral diseases. It can motivate individuals to cope in unhealthy ways that foster oral diseases. Chronic stress also contributes to high allostatic load that can lead to the dysfunction of physiological systems critical to homeostasis, and thus affect the underlying mechanisms of diseases progression, more generally.
\end{abstract}

Methods: It was ahospital based cross sectional study which is completed in the period of 4 months. Total 511 patient were included in the study. A pretested questionnaire was used for data collection. The questionnaire included socio-demographic status, oral health practice. Stress was measured by using modified dental anxiety stress scale questionnaire having score 0 to 3 from never to severe stress. Three questions were reversed due to positive answer. Total score of stress was calculated by combing each score of every question. Total score is divided into three scale, low stress (0-14), Moderate stress (15-30) and severe stress (31- 45).

Ethical permission was obtained from the ethical committee of Taibah University College of Dentistry. The statistical analysis was performed by the Statistical Package for Social Science (SPSS) version 21 (SPSS Inc., Chicago, IL, USA). The significant value was obtained by using Chi Square test and $\mathrm{P}<0.05$ is set to be significant.

Results: Total study participants were 511 among them males 258 and females 253 . Females (65\%) were having severe stress as compared to males $(35 \%)$ and there was no significant relation with gender $(\mathrm{P}=0.170)$. Mostly younger age group (20-30 years) were under high stress $(52 \%)$. Fifty eight percent of participants suffering from severe stress were smokers $(\mathrm{P}<0.000)$ and $68 \%$ of the participants were having bleeding gum who suffered from severe stress $(\mathrm{P}=0.009)$. Thirty nine percent of severe stress participants were cleaning their teeth only occassionally $(\mathrm{P}=0.044)$ and among them $13 \%$ never cleaned their teeth $(\mathrm{P}<0.000)$. Regarding brushing of teeth maximum number of participants from all level of stress were using brush and toothpaste for cleaning of their teeth that was $66 \%, 77 \%$ and $68 \%$ respectively $(\mathrm{P}=0.014)$. Only $10 \%$ of severe stress participants used nothing to clean interdental space $(\mathrm{P}=0.469)$.

Conclusion: It was observed that female and younger participants had severe stress. Among them more than fifty percent were smoker and having complain of bleeding gum. Number of severe stress participants were cleaning their mouth occasionally and some were not using interdental cleaning aids.

Keywords: Bleeding gum; Interdental space; Oral hygiene; Stress, smokers; Taibah University

(C)2018 The Authors. Published by the JScholar under the terms of the Creative Commons Attribution License http://creativecommons.org/licenses/by/3.0/, which permits unrestricted use, provided the original author and source are credited. 


\section{Introduction}

Stress is unavoidable process and is increasing day by day in everyone's life [1]. It's defined in general as the need to make a behavioral adjustment to environmental changes. It can also be defined as adaptive response of an organism to a threatening stimulus, which provides the link between the psychological and physiological processes that are associated in the onset of the disease [2]. And it is a part of the human condition that is present universally, but to varying degrees, and has different effects on individuals [3].

Chronic stress is likely to contribute to the progressive long term development of oral diseases through atleast two distinguishable pathways. First, stress can motivate individuals to cope in unhealthy ways that foster oral diseases (e.g., substance use, including illicit drugs, alcohol and tobacco, poor diet). Second, chronic stress contributes to high allostatic load that canlead to the dysfunction of physiological systems critical to homeostasis, and thus affect the underlying mechanisms of diseases progression, more generally [4].

Stress has been defined in general as the need to make a behavioral adjustment to environmental changes. It can also be defined as adaptive response of an organism to a threatening stimulus, which provides the link between the psychological and physiological processes that are associated in the onset of the disease $[5,16]$. While there seems to be a common belief that psychosocial stress affects oral hygiene behavior, this assumption has rarely been proved.

Periodontitis is an inflammatory response of the periodontium, which involves the destruction of investing tissues around the teeth and results in loss of tooth support and leading to tooth loss. Although, bacterial pathogens are required to initiate the disease process [7-9]. It is found in $5-20 \%$ of most adult populations worldwide [10,11]. Most studies have found that periodontitis affects majority of the adult population after the age of 35-40 years[12].The etiological significance of biological and behavioral risk factors for periodontal diseases, such as smoking, advancing age, oral hygiene, and systemic diseases like diabetes mellitus has already been established[13-17]. Other factors such as stress, depression and anxiety are not yet confirmed as absolute risk conditions, but have been identified in some observational studies [18-20].

The contribution of psychological factors to the development and progression of the periodontal disease has recently become an area of increased research activity. Studies indicated that there might be strong relationships between stress, depression, and periodontal disease demonstrating convincing linkages between depression and elevated cortisol levels, negligence of oral hygiene, pocket depth, attachment loss, and tooth loss [21]. Mannem and Chava [22] found stress to be an important risk factor for periodontal disease. Regarding to smoker people the studies shows that's smoking is more prevalent in depression patients $[23,24]$. And among the many harmful oral habits, which are believed to be induced by emotional disturbances, smoking is possibly the most important in relation to worsened periodontal conditions [25].
Emotional conditions are suggested to cause alterations in dietary intake and affecting periodontal health with indirect pathway. Psychological factors affect the choice of foods through the physical consistency of the diet, and the quantities of food eaten during stressful periods is likely to cause an increase in the accumulation of plaque. Considering that psychological stress and plaque may act synergistically on the concentration of periodontal IL- $1 \beta$, if the neglect of oral hygiene behavior occurs as a result of mental stress, the concentration of periodontal IL- $1 \beta$ might reach maximum levels [26, 27].

\section{Aim of this study}

To know relationship of stress with oral hygiene practice among the patients visiting the National Guard Hospital and Military Hospital, Madinah, Saudi Arabia.

\section{Methods}

This was a hospital based cross sectional study conducted over a period of four months from January 2017 to April 2017. The patients were included in the study who visited the dental outpatient department (OPD) of National Guard Hospital and Sultan Military Hospital of Madinah city. These two hospitals are covering the patients and their family who works in the National Guard and Military respectively. Convenient sampling methods that means the males or females who visited in the dental OPD selected the patients. The purpose of the study was explained to each patient by the interviewer before taking interview and verbal consent was taken. Total 511 patients gave answer properly. Those patients who did not agree to be interviewed or gave incomplete answer were excluded from the study.

A pretested questionnaire was used for data collection. The questionnaire included socio-demographic status, oral health practice, visiting dentist and smoking habits. Stress was measured by using modified dental anxiety stress scale questionnaire having score 0 to 3 from never to severe stress. Three questions were reversed due to positive answer. Total score of stress was calculated by combing each score of every question. Total score is divided into three scale, low stress (014), Moderate stress (15-30) and severe stress (31-45). The patients were divided into three age groups ranging from 20-30, 31-40, and above 40 years.

Ethical permission for the study was obtained from the ethical committee of Taibah University College of Dentistry. The Microsoft Office Excel was used to collect data. The statistical analysis was performed by the Statistical Package for Social Science (SPSS) version 21 (SPSS Inc., Chicago, IL, USA). The significant value was obtained by using Chi Square test and $\mathrm{P}<0.05$ is set to be significant. 


\section{Results}

The total study participants consisted of 511 and among them males 258 and females 253 . It was observed that more females $(65 \%)$ were having severe stress as compared to males (35\%) and there was no significant relation withgender $(\mathrm{P}=0.170)$ Table 1.

Table 1: Relation of stress with gender

\begin{tabular}{|l|l|l|l|}
\hline Stress level & Male N\% & Female N\% & Total N\% \\
\hline Less stress & 4955 & 4045 & 89100 \\
\hline $\begin{array}{l}\text { Moderate } \\
\text { stress }\end{array}$ & 19851 & 19349 & 391100 \\
\hline Severe stress & 1135 & 2065 & 31100 \\
\hline
\end{tabular}

$\mathrm{P}=0.170$ Not significant

It was also observed that more number of participants who were under high stress falls in the age group of $20-30$ years (52\%) as compared to other groups Table 2.

Table 2: Relation of stress with age

\begin{tabular}{|l|l|l|l|l|}
\hline $\begin{array}{l}\text { Stress } \\
\text { level }\end{array}$ & $\begin{array}{l}20-30 \\
\text { yrs N\% }\end{array}$ & $\begin{array}{l}31-40 \\
\text { yrs N\% }\end{array}$ & $\begin{array}{l}>40 \text { yrs } \\
\text { N\% }\end{array}$ & Total N\% \\
\hline Less stress & 6169 & 1820 & 1011 & 89100 \\
\hline $\begin{array}{l}\text { Moderate } \\
\text { stress }\end{array}$ & 23961 & 11329 & 3910 & 391100 \\
\hline $\begin{array}{l}\text { Severe } \\
\text { stress }\end{array}$ & 1652 & 1032 & 516 & 31100 \\
\hline
\end{tabular}

Table 3 shows that $58 \%$ of participants suffering from severe stress were smokers and it was found that level of stress is highly significant relation with smoking $(P<0.000)$. Sixty eight percent of the participants were having bleeding gum who suffered from severe stress $(P=0.009)$ Table 4 .

\begin{tabular}{|l|l|l|l|}
\hline Stress level & Yes N\% & No N\% & Total N\% \\
\hline Less stress & 1921 & 7079 & 89100 \\
\hline $\begin{array}{l}\text { Mo d e r a t e } \\
\text { stress }\end{array}$ & 16141 & 23059 & 391100 \\
\hline Severe stress & 1858 & 1342 & 31100 \\
\hline
\end{tabular}

$\mathrm{P}>0.000$ highly significant

Table 4: relation of stress with the bleeding gum

\begin{tabular}{|l|l|l|l|}
\hline Stress level & Yes N\% & No N\% & Total N\% \\
\hline Less stress & 3539 & 5461 & 89100 \\
\hline $\begin{array}{l}\text { Mo d e r a te } \\
\text { stress }\end{array}$ & 21154 & 18046 & 391100 \\
\hline Severe stress & 2168 & 1032 & 31100 \\
\hline
\end{tabular}

$\mathrm{P}=0.009$ Highly significant
It was surprisingly to observe that $39 \%$ severe stress participants were cleaning their teeth only occassionally ( $\mathrm{P}$ $=0.044)$ and among them $13 \%$ never cleaned their teeth $(\mathrm{P}$ $<0.000)$ Table $5 \& 6$.

Table 5: Relation of stress with the cleaning of teeth.

\begin{tabular}{|l|l|l|l|l|l|}
\hline $\begin{array}{l}\text { Stress } \\
\text { level }\end{array}$ & $\begin{array}{l}\text { Morn- } \\
\text { ing only } \\
\text { N\% }\end{array}$ & $\begin{array}{l}\text { Evening } \\
\text { only N } \\
\%\end{array}$ & $\begin{array}{l}\text { Morning } \\
\text { evening } \\
\text { N\% }\end{array}$ & $\begin{array}{l}\text { Occa- } \\
\text { sional- } \\
\text { lyN \% }\end{array}$ & $\begin{array}{l}\text { Total } \\
\text { N \% }\end{array}$ \\
\hline $\begin{array}{l}\text { Less } \\
\text { stress }\end{array}$ & 67 & 910 & 6067 & 1416 & $\begin{array}{l}89 \\
100\end{array}$ \\
\hline $\begin{array}{l}\text { Mod- } \\
\text { erate } \\
\text { stress }\end{array}$ & 4411 & 4712 & 23861 & 6216 & $\begin{array}{l}391 \\
100\end{array}$ \\
\hline $\begin{array}{l}\text { Severe } \\
\text { stress }\end{array}$ & 26 & 310 & 1445 & 1239 & $\begin{array}{l}31 \\
100\end{array}$ \\
\hline
\end{tabular}

$\mathrm{P}=0.044$ level of stress is significant with cleaning

Table 6: Relation of stress with the time of cleaning teeth

\begin{tabular}{|l|l|l|l|l|l|}
\hline $\begin{array}{l}\text { Stress } \\
\text { level }\end{array}$ & $\begin{array}{l}\text { One } \\
\text { time N } \\
\%\end{array}$ & $\begin{array}{l}\text { Two } \\
\text { time N } \\
\%\end{array}$ & $\begin{array}{l}\text { Occa- } \\
\text { sionally } \\
\mathrm{N} \%\end{array}$ & $\begin{array}{l}\text { Never } \\
\text { clean } \\
\mathrm{N} \%\end{array}$ & $\begin{array}{l}\text { Total } \\
\mathrm{N} \%\end{array}$ \\
\hline Less stress & 78 & 6573 & 1618 & 11 & 89100 \\
\hline $\begin{array}{l}\text { Moderate } \\
\text { stress }\end{array}$ & 8823 & 23259 & 6817 & 31 & 391100 \\
\hline $\begin{array}{l}\text { Severe } \\
\text { stress }\end{array}$ & 516 & 1548 & 723 & 413 & 31100 \\
\hline
\end{tabular}

$\mathrm{P}<0.00$ level of stress is highly significant with time of cleaning

Regarding brushing of teeth maximum number of participants from all level of stress were using brush and toothpaste for cleaning of their teeth that was $66 \%, 77 \%$ and $68 \%$ respectively. $\mathrm{P}=0.014$

Table 7: Relation of stress with the tools of cleaning teeth

\begin{tabular}{|l|l|l|l|l|l|}
\hline $\begin{array}{l}\text { Stress } \\
\text { level }\end{array}$ & $\begin{array}{l}\text { Brush+ } \\
\text { toothpas- } \\
\text { teN \% }\end{array}$ & $\begin{array}{l}\text { Brush+ } \\
\text { miswakN } \\
\%\end{array}$ & $\begin{array}{l}\text { iswakN } \\
\%\end{array}$ & $\begin{array}{l}\text { Noth- } \\
\text { ingN } \\
\%\end{array}$ & $\begin{array}{l}\text { To- } \\
\text { talN } \\
\%\end{array}$ \\
\hline $\begin{array}{l}\text { Less } \\
\text { stress }\end{array}$ & 5966 & 2124 & 67 & 33 & $\begin{array}{l}89 \\
100\end{array}$ \\
\hline $\begin{array}{l}\text { Mod- } \\
\text { erate } \\
\text { stress }\end{array}$ & 30277 & 7018 & 133 & 62 & $\begin{array}{l}391 \\
100\end{array}$ \\
\hline $\begin{array}{l}\text { Severe } \\
\text { stress }\end{array}$ & 2168 & 412 & 310 & 310 & $\begin{array}{l}31 \\
100\end{array}$ \\
\hline
\end{tabular}

$\mathrm{P}=0.014$ level of stress is significant with tools of cleaning 
Table 8: Relation of stress with tools of cleaning in between teeth

\begin{tabular}{|l|l|l|l|l|l|}
\hline $\begin{array}{l}\text { Stress } \\
\text { level }\end{array}$ & $\begin{array}{l}\text { Brush } \\
\mathrm{N} \%\end{array}$ & $\begin{array}{l}\text { Dental } \\
\text { floss N } \\
\%\end{array}$ & $\begin{array}{l}\text { Tooth- } \\
\text { pick N } \\
\%\end{array}$ & $\begin{array}{l}\text { Noth- } \\
\text { ingN \% }\end{array}$ & $\begin{array}{l}\text { Total N } \\
\%\end{array}$ \\
\hline $\begin{array}{l}\text { Less } \\
\text { stress }\end{array}$ & 2225 & 2528 & 3236 & 1011 & 89100 \\
\hline $\begin{array}{l}\text { Mod- } \\
\text { erate } \\
\text { stress }\end{array}$ & 9825 & 14938 & 11830 & 267 & 391100 \\
\hline $\begin{array}{l}\text { Severe } \\
\text { stress }\end{array}$ & 929 & 929 & 1032 & 310 & 31100 \\
\hline
\end{tabular}

$\mathrm{P}=0.469$ Level of stress is not significant

The relationship between the level of stress and cleaning in between the teeth was not significant as $p$ value $=0.469$. The participants who were in severe stress, among them only $10 \%$ never used any tools of cleaning the teeth as well as for interdental cleaning.

\section{Discussion}

This cross sectional study was conducted to determine the association between stress and oral health practice and oral hygiene among the patients visited National Guard Hospital and Military Hospital, Madinah, Kingdom of Saudi Arabia.

Brushing, interdental cleaning, tongue hygiene are the most important tools for better oral health. The oral health related factors are associated with poor social and emotional well being but it is not possible to determine the exact pathway [28]. Stress can increase the frequency of mouth sores. Students often have mouth sores during their school year but no more or fewer during holidays [29]. It can also cause facial pain, grinding teeth, poor oral hygiene and gum diseases. Little is mentioned in the literature about mental stress relationship to oral health but some researchers found that stress were a risk factor for periodontal diseases. We have tried to find that oral hygiene practice is affected due to stress and this leads to affect oral health.

In the present study all the patients were aware about the importance of brushing but we found significant relation between the stress and oral hygiene. In our study percentage of severe stress was high among female (65\%) as compared to male (35\%) which shows in table 1 . Mostly youngers (20 - 30 years) were having severestress (52\%). In several studies rate of depression was higher among female [30-31]. Stress among female high might be due to restriction in outdoor activity and confined more inside which is common in some Saudi community and this leads to excessive use of smart phones on social media. The other reason might be for female jobs are only in few sector. Pratt et al [32] reported that adult aged 20 years and over stress were more likely to be smokers than those without stress. This study also shows the patients of severe stress were mostly smokers and it has highly significant relation between severe stress and smoking $(P>0.00)$. This study was supported by the previous study by Choi et al [33].
Table 4 shows that $65 \%$ patients having severe stress complained of bleeding gum. This study strongly supported by the notion discussed by several authorsthat stress effect on gingiva and periodontal health $[34,35]$. It might be stress induced neglect of oral hygiene practice and not giving attention on oral hygiene maintanance and this leads to oral health problem like bleeding gum, gingivitis, periodontitis and dental caries. Several other scientists also studied and found similar findings [36-38]. Lin et al found dental pain which was associated with stress[39]. A study involving high school students reported that the higher the level of stress during the university examination and that leads to higher perception of the oral diseases [40].

Table 5 shows that 39\% patient suffering from severestress were cleaning their teeth occassionally. This shows that people in severe stress do not give attention on oral hygiene practice which leads to further oral infection like gingivitis and periodontitis. In term of brushing, $61 \%$ were cleaning their mouth at least once daily (Table 6) and similar data were reported by researcher [41]. Among the all patients 10\% were neither using any brush and nor using any tools to clean interdental space (Table 7 and 8). Segura and Sheiham found possitive association between work related demands and periodontal diseases indicated by bleeding or pocket [42].

\section{References}

1) Bhushan K, Prabhdeep K, Sandhu S (2014) Psychological stress related oral health problem -dental perspective. IJRID 4: 43-47.

2) Honkala E, Maidi D, Kolmakow S (1992) Dental caries and stress among South African political refugees. Quintessence Int 23: 579-83.

3) Cooper CL, Cooper EB, Eaker LH. (1988) Living with Stress (1st edn) Middlesex, UK: Penguin. 11-12.

4) Shankardass K (2012) Place based stress and chronic diseases: A systems view of environmental determinants. In: O Campo P, Dunn JR,, editors. Rethinking social epidemiology: towards a science of change. New York: Springer Publishing Company 117-118.

5) Genco RJ, Ho AW, Kopman J, Grossi SG, Dunford RG, Tedesco LA (1998) Models to evaluate the role of stress in periodontal disease. Ann Periodontol 3:288-302.

6) Tang C, Quinonez RB, Hallett K, Lee JY, Whitt JK (2005) Examining the association between parenting stress and the development of early childhood caries. Community Dent Oral Epidemiol 33:454-460.

7) Williams RC (1990) Periodontal disease. N Engl J Med 322:373-82.

8) Birkedal-Hansen H (1993) Role of cytokines and inflammatory mediators in tissue destruction. J Periodontal Res 28:500-10.

9) Johannsen A, Asberg M, Söder PO, Söder B (2005) Anxiety, gingival inflammation and periodontal disease in non-smokers and smokers- an epidemiological study. J Clin Periodonto 32:488-491.

10) J. M. Albandar (2005) "Epidemiology and risk factors of periodontal diseases," Dental Clinics of North America 49: 517-532.

11) D. R. Haynes (2006) "Emerging and future therapies for the treatment of bone loss associated with chronic inflammation," Inflammopharmacology 193-197.

12) J. Khalili (2008) "Periodontal disease: an overview for medical practitioners," Likars'ka sprava 10-21. 
13) Haber J, Kent RL (1992) Cigarette smoking in a periodontal practice. J Periodontol 63:100-106.

14) Beck JD (1994) Methods of assessing risk for periodontitis and developing multifactorial models. J Periodontol 65: 468-478.

15) Grossi SG, Zambon JJ, Ho AW, Koch G, Dunford RG, Machtei EE, et al. (1994) Assessment of risk for periodontal disease. I. Risk indicators for attachment loss. J Periodontol.65:260-267.

16) Offenbacher S (1996) Periodontal diseases: Pathogenesis. Ann Periodontol 1:821-878.

17) Vettore MV, Leão AT, Monteiro Da Silva AM, Quintanilha RS, et al. (2003) The relationship of stress and anxiety with chronic periodontitis. J Clin Periodontol 30:394-402.

18)Monteiro da Silva AM, Oakley DA, Newman HN, Nohl FS, Lloyd HM (1996) Psychosocial factors and adult onset rapidly progressive periodontitis. J Clin Periodontol 23:789-94.

19) Moss ME, Beck JD, Kaplan BH, Offenbacher S, Weintraub JA, Koch GG, et al. (1996) Exploratory case-control analysis of psychosocial factors and adult periodontitis. J Periodontol.67:1060-109.

20) Ng SK, Keung Leung W (2006) A community study on the relationship between stress, coping, affective dispositions and periodontal attachment loss. Community Dent Oral Epidemiol. 34:252-266.

21) Rosania AE, Low KG, McCormick CM, Rosania DA (2009) Stress, depression, cortisol, and periodontal disease. J Periodontol.80:260-266.

22) Mannem S, Chava VK (2012) The effect of stress on periodontitis: A clinicobiochemical study. J Indian Soc Periodontol 16:365-369.

23) Lasser K, Boyd JW, Woolhandler S, Himmelstein DU, McCormick D, Bor DH (2000) Smoking and mental illness: A populationbased prevalence study. JAMA. 284:2606-2610.

24) McClave AK, McKnight-Eily LR, Davis SP, Dube SR (2010) Smoking characteristics of adults with selected lifetime mental illnesses: Results from the 2007 National Health Interview Survey. Am J Public Health. 100:2464-2472.

25) Haber J (1994) Smoking is a major risk factor for periodontitis: current opinion in periodontology. In: Williams RC, Yukna RA, Newman MG, editors. Philadelphia: Current Science 12-18.

26) Linli C, Kunlu H (2006) Mental stress and its association with periodontal health College of Oral Medicine, Taipei Medical University, Taipei, Taiwan, ROC. J Dent Sc 1:155-160.

27) Suchday S, Kapur S, Ewart CK, Friedberg JP (2006) Urban stress and health in developing countries: Development and validation of a neighborhood stress index for India. Behav Med 32:77-86.

28) Vered Y, Soskolne V, Zini A, Livny A, Sgan-Cohen HD (2011) Psychological distress and social support are determinants of changing oral health status among an immigrant population from Ethiopia. Community Dent Oral Epidemiol 39:145-153.

29) Ravishankar T.L, Tasneem S A, Gowhar O (2014) Effect of Academic Stress on Plaque and Gingival Health among Dental Students of Moradabad, India. JIAP 16: 115-120.

30) Wennstrom A, Boman UW, Ahlqwist M, Bjorkelund C, Hakeberg M (2015) Perceived menta stress in relation to oral health over time in middle aged Swedish women. Community Dent Health 32: 241-246.

31) Kim YS, Kim HN, Lee JH, Kim SY, Jun EJ, Kim JB (2017) Association of stress, depression and suicidal ideation with subjective oral health status and oral functions in Korean adults aged 35 years or more. BMC Oral Health 17:101

32) Pratt LA, Bordy DJ (2010) Depression and smoking in the US household population aged 20 and over, 2005-2008. NCHS Data Brief 34:1-8.
33) Choi HA, Lee DS, Kim YJ (2011) Analysis on depression and suicidal ideation of Korean Female adukts by using Korea National Health and Nutrition Examination Survey. J Korean Data Anal Soc 13: 709-720.

34) Croucher R, Marcenes WS, Torres MC, Hughes WS, Sheiham A (1997) The relationship between life events and periodontitis. J Cinc Periodont 24: 39-43.

35) Linden GJ, Mullally BH, Freeman R (1996) Stress and the progression of periodontal disease. J clinc Periodont 23: 675 -680.

36) A. T. Merchant, W. Pitiphat, B. Ahmed, I. Kawachi, and K. Joshipura (2003) "A prospective study of social support, anger expression and risk of periodontitis in men," Journal of the American Dental Association. 1591-1596.

37) W. S. Marcenes and A. Sheiham (1992) "The relationship between work stress and oral health status," Social Science and Medicine 35: 1511-1520.

38) M. E. Moss, J. D. Beck, B. H. Kaplan et al., (1996) "Exploratory case-control analysis of psychosocial factors and adult periodontitis," Journal of Periodontology. 67: 1060-1069.

39) Lin CS, Niddam DM, Hsu ML, Hsieh JC (2013) Pain catastrophizing is associated with dental pain in a stressful context. J Dent Research 92: 130-135.

40) Prabhu PS (2015) A study on academic stress among higher secondary students Int J Humannities and Soc Science Invention 4: 6367.

41) Vasiliou A, Shankardass K, Nisenbaum R, Quinonez C (2016) Current stress and poor oral health. BMC Oral Health 16: 88

42) Marcenes WS, Sheiham A (1992) The relationship between work stress and oral health status. Soc Sci Med 35: 1511-1520.

Submit your manuscript to a JScholar journal and benefit from:

I Convenient online submission

I Rigorous peer review

ฯ Immediate publication on acceptance

बा Open access: articles freely available online

ब High visibility within the field

- Better discount for your subsequent articles Submit your manuscript at http://www.jscholaronline.org/submit-manuscript.php 